\title{
ЛІНГВІСТИЧНІ ЗАСАДИ НАВЧАННЯ ФОНЕТИКИ В ГІМНАЗЇ
}

Бакум 3. П. Лінгвістичні засади навчання фонетики в гімназії.

У статті обгрунтовано лінгвістичні засади навчання фонетики в старшій школі, визначено ключові питання фонетичної системи, які необхідно конкретизувати у змісті мовної освіти в гімназіях, ліцеях, колегіумах, класах із поглибленим вивченням мови.

Ключові слова: фонетика, фонетична система, мовна освіта.

Бакум 3. П. Лингвистические основы обучения фонетике в гимназии.

В статье обоснованы лингвистические основы обучения фонетике в старшей школе, определены ключевые вопросы фонетической системы, которые необходимо конкретизировать в содержании языкового образования в гимназиях, лицеях, коллегумах, классах с углубленным изучением языка.

Ключевые слова: фонетика, фонетическая система, языковое образование.

Bakum Z. P. Linguistic basics of teaching phonetics in gymnasium

The article investigates linguistic basics for teaching the course of the Ukrainian phonetics at the gymnasium as well as defines key points of its phonetic system which are to be highlighted in the contents of linguistic education on the specialized level of teaching.

Key words: phonetics, phonetic system, language education.

Зміст і принципи методики навчання української мови, рівень досконалості визначається передовсім станом розробки самого курсу мови. Лінгводидактика, на думку О. Текучова, „не може ні існувати, ні розвиватися безвідносно до мовознавства, до лінгвістичної науки в іiї сучасному стані”, спираючись на педагогічну теорію та психологію, вона „все більше і більше формується як наука не лише педагогічна, але певним чином і лінгвістична" [8, 27-28].

Дослідження лінгвістичних засад навчання фонетики в гімназії грунтується на узагальнених висновках науковців, у працях яких визначено положення про мову як особливу систему, іiі структуру, основні одиниці та способи поєднання цих одиниць у мовленні. Адже для засвоєння мови як певної системи учням необхідно навчитися передовсім співвідносити звукові одиниці мови (звуки) зі смисловими одиницями - морфемою, словом, словосполученням, реченням, що, у свою чергу, співвідносяться з реальністю та забезпечують формування мовленнєвих умінь і навичок, потрібних кожній людині.

Фонетичну систему мови досліджували, вирішували питання про основну іiі одиницю такі науковці, як: І. Бодуен де Куртене, О. Курило, 
М. Наконечний, В. Перебийніс, Л. Прокопова, Ф. де Сосюр, С. Тимченко, Н. Тоцька, Л. Щерба.

Мовознавці не оперують логічно вибудованою класифікацією лінгвістичних категорій, тому в низці праць поняття фонетика тлумачиться також по-різному. Пор.: 1. „ Розділ мовознавства, присвячений вивченню звукового складу мови; вивчає умови і способи творення мовних звуків, їх акустичні, а також анатомо-фізіологічні властивості, різні зміни й чергування, взаємозв'язок і взаємозумовленість звукових змін, роль звуків у розрізнюванні значущих елементів мови” $[5,43] ; 2$. „Самостійний розділ мовознавства, який має визначений предмет дослідження - звуковий бік мови в усіх їі проявах, тобто у ньому вивчається звукова система мови у зв'язку з іiі смисловою роллю та різноманітні звукові зміни" $[6,16]$. Як бачимо, дослідники сходяться на тому, що фонетика - розділ мовознавства, предметом вивчення якого $є$ звукова будова мови в різноманітних ії проявах.

У свою чергу звуковий аспект української літературної мови становить систему ії звукових засобів, що у процесі комунікації зливаються в один суцільний мовленнєвий потік, який, залежно від змісту, членується послідовно на фрази, синтагми, фонетичні слова, склади і звуки [7, 1718]. Відповідно до цього звукові одиниці фонетики поділяються на: сегме-

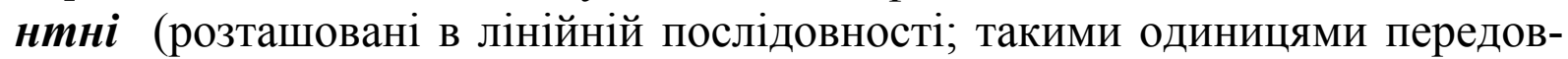
сім є звуки, що визначають матеріальний бік знакових одиниць будь-якого рівня мови: морфем, слів, словосполучень і т. ін.; сполучення звуків утворюють іншу сегментну одиницю - склад; більшими за обсягом одиницями цього рівня прийнято вважати фонетичне слово, такт, синтагму, фонетичну фразу) та суперсегментні (характеризують не окремі звуки чи склади, а фонетичні слова і фрази; нелінійні одиниці забезпечують звукову цілісність слова; до них відносять наголос та інтонацію).

У змісті мовної освіти в середніх навчальних закладах фонетика розглядається як „розділ мовознавчої науки, що описує і пояснює звукову систему мови, умови творення звуків, їх класифікацію, взаємовпливи, чергування і роль у мовленні” [3, 13]. Що ж до нашого витлумачення, то фонетика - це розділ мовознавства, що вивчає артикуляційні й акустичні особливості звуків мови, закономірності їх сполучуваності в мовленнєвому потоці, пов'язані з ними позиційні зміни, наголос, інтонацію, членування мовленнєвого потоку на відрізки. У гімназійному курсі навчання мови варто акцентувати на принциповій різниці фонетики порівняно з іншими лінгвістичними дисциплінами, а саме: фонетика вивчає одиниці, природа яких матеріальна. А з матеріального аспекту в мові, відображеному в мовленні, є звуки, які утворюють слова, речення, текст, за звуковими комплексами стоїть величезний світ значень лексичних, граматичних, стилістичних.

Результати лінгвістичних досліджень упродовж усього розвитку методичної думки $є$ визначальними в теорії та практиці навчання фонетики. Ще в 1948 р. висловлено думку про те, що „з боку вчителів зросли запи- 
ти на консультації, доповіді, семінари з питань наукової фонетики, а також iз проблем методики шкільної фонетики на науковій основі" [11, 13]. На важливість грунтовно розроблених теоретичних засад навчання фонетики вказано і в дисертації А. Медушевського, поданій на здобуття наукового ступеня доктора педагогічних наук „Викладання фонетики і граматики української мови у восьмирічній школі". Згодом цю настанову підтримали науковці С. Дорошенко, О. Караман, М. Пентилюк, Г. Передрій, Н. Тоцька. Лише на чітко окреслених теоретичних засадах навчання фонетики уможливлюється розуміння мови як єдиної, внутрішньо погодженої цілісності; знайомство учнів із тим, як утворюються звуки мовним апаратом людини, які рухи органів мови вимагаються для утворення кожного звука, як правильно членувати слово на склади і визначати в ньому наголос, членувати мовленнєвий потік на фонетичні слова, синтагми, фрази; пояснення явищ літературної вимови, їх зведення в єдину систему; встановлення поняття літературної вимови та ін. Без ознайомлення 3 фонетичною системою мови неможливе їі теоретичне чи практичне вивчення. адже звуки - це матерія мови, поза якою не мислиться саме існування мови слів.

Фонетику як складову загальної структури мови, одну з їі систем розглядає М. Пентилюк: „Таке розуміння дає можливість побудувати вивчення лексики граматики на фонетичній основі, здійснюючи цим самим принцип випереджувального навчання усного мовлення, i вивчати теоретичні відомості з фонетики не ізольовано, а як перший рівень цілісної структури рідної мови" $[3,89]$. Саме з подібних міркувань важливим для лінгводидактики є положення мовознавчої науки про те, що фонетика тісно пов'язана з іншими розділами мовознавства (орфоепією: правила вимови звуків; лексикою: звук є будівельним матеріалом для слова, засобом вираження його значення; графікою: літери перебувають у безпосередньому зв'язку з одиницями, які утворюють фонологічну систему мови і визначають способи позначення звуків мовлення на письмі; морфемікою і словотвором: морфеми, словотворчі засоби утворюються звуками; орфографією: за фонетичним принципом, написання відповідає звуковому вираженню слова; морфологією: чергування звуків фонетичним засобом вираження низки граматичних значень; синтаксисом: інтонаційна організація речення, логічний і фразовий наголос виявляються лише в реченні як комунікативній одиниці; стилістикою: явища звукового оформлення прозового і віршованого мовлення, зокрема ритмічне членування, алітерація й асонанси, звуконаслідування, звукові форми тощо). Як видно, мовні одиниці мають вияв у звуковій формі, а відтак вивчення мови - граматичної будови і словникового складу - передбачає глибоке вивчення їі фонетичної системи.

Нині мовознавцями чітко визначено й завдання фонетики (Ю. Карпенко, Н. Тоцька), які полягають в описі звукової системи мови, вияві та описі законів, які діють у мові, визначенні часткових та загальних закономірностей у фонетичних явищах, виявленні та описі ролі звуків у мові як 
засобі спілкування, що і становить лінгвістичні основи навчання гімназійного курсу фонетики. Звуки визначають матеріальний аспект знакових одиниць будь-якого рівня мови: морфем, слів, словосполучень і об'єднують усі рівні, систему мови в єдине ціле. 3 огляду на зазначене, указуємо на важливість вивчення фонетичних одиниць і фонетичних закономірностей, що стосуються передовсім розгляду й опису звука в різноманітних аспектах. Через те що звук $є$ результатом дії артикуляторних органів людини, цей аспект услід за розвідками мовознавства в гімназійному курсі також доцільно виокремити і зберегти назву артикуляторний, або фізіологічний; із тієї причини, що звук і будь-яке фонетичне явище має фізичну природу, створюється можливість описувати фонетичне явище як явище акустики, а такий аспект називати акустичний. Тому будь-які фонетичні явища розглядаємо і з акустичних, і з фізіологічних позицій. Що ж до аналізу звука в процесі обміну інформацією, тобто під час сприймання, розуміння й опису, виникає необхідність вивчати його у функційному аспекті.

Згідно з виділеними аспектами у вивченні звукового мовлення, акцентуємо, що фонетика в широкому розумінні має два розділи: фонетику (фонетичний аспект) і фонологію (фонологічний аспект). Відповідно, одиницею фонетики є звук мовлення, одиницею фонології- фонема. „Фонетика та фонологія - два якнайтісніше взаємопов'язані аспекти дослідження і практичного опису, зокрема $з$ лінгводидактичною метою, одних i тих самих явищ - звукових одиниць, що становлять матеріальну основу мовної комунікації”, - зазначає Н. Тоцька $[6,16]$. Фонетичний і фонологічний напрямки тісно поєднані, передбачають одне одного, не існують самостійно. Так, не можна охарактеризувати лінгвістичну функцію того чи того протиставлення звукових одиниць (протиставлення твердих і м'яких, глухих i дзвінких), не даючи артикуляційно-акустичної характеристики відповідних одиниць. 3 іншого боку, сам по собі фонетичний опис важливий не як самоціль, а як засіб для виявлення функційних характеристик звукових одиниць, для опису фонологічної системи.

Проблему реалізації фонологічного підходу в навчанні фонетики в 90-х роках минулого століття порушує Г. Передрій: „Учні мають передовсім одержати чітке уявлення про роль звуків як мовних одиниць, які служать для утворення, розрізнення і розпізнавання одиниць вищого рівня" [4, 12]. Однак подібні пропозиції, на жаль, залишалися тільки декларацією, що чекали негайного впровадження в освітній процес. Нині з упевненістю можна стверджувати про введення функційного аспекту до гімназійного курсу української мови, що вивчає власне лінгвістичну характеристику звуків, а саме те, яку функцію виконують вони в процесі комунікації як знаки для утворення і розмежування слів.

Відтак необхідно підтримати позицію учених (С. Дорошенко, С. Караман, О. Караман, А. Медушевський, Г. Передрій), які упродовж трива- 
лого часу пропагують ідею введення до шкільного курсу фонетики такого поняття, як фонема. Зауважимо, що в науковому обігу лінгводидакти послуговувалися цим терміном здавна, однак його практично не залучали до шкільних програм і підручників з української мови.

На важливість розуміння учнями фонеми ще в 50-х роках минулого століття вказує відомий російський методист I. Устрицький: „3 погляду соціального нас цікавлять не всі фактично вимовлювані звуки, а лише ті основні, соціально оброблені, які відіграють у мові смислорозрізнювальну роль, так звані фонеми" $[11,31]$. Згодом цю думку продовжує А. Медушевський. Автор хоча й науково не обгрунтовує доцільність уведення в теорію та практику навчання мови названого терміна, однак займає чітку позицію і наголошує на тому, що в учнів має бути сформоване поняття про фонему. У подальшому ідею введення фонеми до шкільного курсу мови порушує й О. Караман: „У процесі спілкування людина розпізнає не окремий звук, а тип звука, одиницю мовної системи, яка здатна розрізняти слова та їх форму - фонему”, це означає, що ,,терміном звук у шкільній практиці позначаються два різні поняття: 1) найменша одиниця мови - поняття про звук з погляду його смислової ролі (фонеми); 2) одиниця мовлення - фізичне явище, що являє собою елемент мовленнєвого потоку, який твориться органами мовлення і сприймається органами слуху” [2, 23].

Автори низки методичних указівок для вчителів також оперують поняттям „фонема”, однак не відмежовують його від терміна „звук”, на що вказує такий запис: „звук (фонема)...”. М. Доленко, І. Дацюк у посібнику „Вивчення української мови в 4 класі” зауважують, що фонеми видозмінюються і виступають у вигляді варіантів - конкретних звуків за певних конкретних умов. Тут же подано визначення: „Звуки, за допомогою яких розрізняються слова та їх форми, називаються фонемами”. Таке ототожнення є неприйнятним з наукової позиції, оскільки, як зазначалося вище, звук - акустичний та артикуляційно-фізіологічний елемент мовлення; фонема - абстрактна, функційна одиниця мови. Саме тому їх не можна ставити на один рівень, щоправда, будучи різними елементами звукової системи, вони перебувають у певній єдності одне з одним: фонеми реалізуються у звуках. Проте це не означає, що кількість фонем указує на існування такого ж числа звуків, а виділення того чи того звука свідчить про наявність у мовленні відповідної фонеми.

Отже, розуміння учнями фонеми сприяє результативному впровадженню в навчання української мови ідей фонологічного підходу до ролі звуків у мовленнєвій діяльності, націлює зусилля вчителів на ефективне пояснення функцій звуків мови.

Учені-методисти спираються на основні положення лінгвістичної науки й у проблемах складу як найменшої цілісної вимовної одиниці об'єкта теоретичних і прикладних досліджень у загальній фонетиці та фонетиці окремих мов. Питання, пов'язані з теорією складу, з особливостями 
його будови, складоподілом і виділенням найтиповіших моделей складів, із дослідженням артикуляційно-акустичної природи складу були і $є$ предметом пильної уваги багатьох відомих лінгвістів: Р. Аванесова, І. Бодуена де Куртене, Л. Бондарко, Л. Зіндера, Н. Свєтозарової, Л. Щерби. Різні аспекти вивчення складу репрезентовано в численних працях українських мовознавців: А. Багмут, О. Бас-Кононенко, В. Брахнова, М. Жовтобрюха, Л. Прокопової, Н. Тоцької.

У лінгвістиці виокремлено два напрями до визначення складу. За фонетичного підходу загальною ознакою, що об'єднує голосний і розташовані навколо нього приголосні в один склад, уважається певна фонетична властивість; за фонологічного - голосний і приголосні об'єднуються у склад завдяки наявним у мові правилам сполучуваності фонем. Функційне значення складу різноманітне. Фонетичний склад $є$ формою організації звуків у слові, фонологічний склад - формою організації фонем [5, 342].

Таким чином, доцільно досліджувати сполучуваність фонем як у межах значущих одиниць (слово або морфема), так і в межах складу, а межі складу варто визначати на основі фонетичних критеріїв, тобто вивчати фонетичну природу складу. У гімназійному курсі фонетики розглядаємо позиції, у яких відстоюється думка про те, що складоподіл відбувається частіше всього не на основі правил сполучуваності фонем в односкладних словах (лише в односкладних словах межі складу виражені чітко), а на грунті різноманітних фонетичних правил.

Аналіз наукових проблем, пов'язаний із просодичними характеристиками мовлення, обгрунтуванням певних ознак в артикуляційному, акустичному та перцептивному аспектах, розгляд їх функціонування в мовленні складають низку питань, що орієнтують процес навчання української мови в сучасній школі на інтенсивний мовленнєвий розвиток учнів, формування і розвиток здатності дотримуватися в процесі спілкування всіх стилістичних, функційно-стильових, комунікативних і етичних норм.

Наголос та інтонація належать, як вище вже зазначалося, до нелінійних фонетичних одиниць, що не мають власних матеріальних засобів вираження, не існують ізольовано, не можуть вимовлятися окремо і виділятися зі складу лінійних одиниць, іншими словами, вони „в потоці мовлення не становлять окремої ланки, а накладаються на вже наявні сегменти" $[1,8]$.

Хоча інтонація мовлення ще й досі лишається однією з найменш досліджених напрямків методики мови, все ж необхідно відзначити, що окресленій проблемі присвячено чимало праць видатних психологів, лінгвістів (А. Багмут, Л. Бондарко, Л. Близниченко, С. Бризгунова, Н. Жинкін, Л. Куліш, М. Панов, А. Реформатський, Н. Тоцька), які великою мірою можуть слугувати розвиткові вітчизняної методичної думки.

Важливі експериментально-фонетичні дослідження проводилися у відділі експериментальної фонетики Інституту української мови (Інститут мовознавства ім. О. Потебні - авт. 3. Бакум). Вони скеровувалися насампе- 
ред на визначення інтонаційних особливостей комунікативних типів і видів речень різновидів думки, встановлення складної взаємодії тональних, динамічних і темпоральних компонентів інтонаційної організації змісту висловлення. При цьому робилися спроби вичленувати з інтонації специфіку передачі емоційно-вольового стану мовця (А. Багмут, Л. Близниченко, І. Борисюк та ін.). Проводилася робота щодо встановлення експериментально-фонетичним шляхом особливостей складоподілу в сучасній українській мові (В. Брахнов), інтонаційних особливостей вставності (Н. Плющ) та сполучникових (А. Грищенко).

Окрім того, інтонація оформлює різноманітні синтаксичні конструкції і типи речень, за допомогою інтонації мовлення членується на інтонаційно-смислові відрізки - синтагми; нарешті, інтонація бере участь у вираженні думок, почуттів, волевиявлень людини; словесний наголос $\epsilon$ обов'язковою ознакою слова.

Отже, є всі підстави вважати фонетику основою гімназійного курсу мови. З'ясовуючи з учнями граматичне або лексичне значення слів, необхідно йти від їх фонетичної (звукової) структури, оскільки фонетична форма слова за своєю природою первинна. Без усвідомленого засвоєння фонетики неможливе вивчення інших розділів науки про мову. Важливо сформувати вміння в учнів бачити, у яких звукових відношеннях опиняються слова, що об'єднуються у словосполучення та речення. Знання з фонетики конче потрібні для засвоєння особливостей усного мовлення, законів писемного мовлення, орфоепії - норм літературної вимови, зокрема правильної вимови звуків та їх сполучень у мовленнєвому потоці, тобто у словах, фразах, для усвідомлення виражальних можливостей інтонації, а також її компонентів.

\section{Література}

1. Бондар О. І. Сучасна українська мова: Фонетика. Фонологія. Орфоепія. Графіка. Орфографія. Лексикологія. Лексикографія: [навч. посібн.] / Бондар О. І., Карпенко Ю. О., Микитин-Друженець М. Л. - К. : Академія, 2006. - 368 с.

2. Караман О. В. Формування в учнів орфографічних умінь і навичок у процесі вивчення фонетики: дис. канд. пед. наук: 13.00.02 / Караман Ольга Володимирівна. - К., 1994. - 191 с.

3. Методика вивчення української мови в школі: [посібник для вчителів] / Білясв О. М. , Мельничайко В. Я., Пентилюк М. І. та ін. - К.: Радянська школа, 1987. - 246 с.

4. Передрій Г.Р. Особливості вивчення за новим підручником фонетики, орфоепії, графіки, орфографії / Г. Р. Передрій // Українська мова і література в школі. - 1991. - № 11. - С. 10-16.

5. Сучасна українська літературна мова: Вступ. Фонетика / за заг. ред. І. К. Білодіда. - К. : Наук. думка, 1969. - 436 с.

6. Сучасна українська літературна мова: [підручник] / за заг. ред. А. П. Грищенка. - [3-тє вид. доповн.]. - К. : Вища школа, 2002. - 439 с.

7. Сучасна українська літературна мова: [підручник] / за ред. М. Я. Плющ. - К. : Вища школа, 1994. - 414 с. 
8. Текучев А. В. Методика русского языка в средней школе: [учебник для студ. педагогических ин-тов] / А. В. Текучев. - [2-е изд. перераб. и доп]. - М. : Просвещение, 1970. - 606 с.

9. Тихоша В. І. Рідна мова: [підручник для 10 класу гімназій, ліцеїв та шк. 3 поглибл. вивч. укр. мови] / Тихоша В. І.,Плющ М. Я., Караман С. О. - К. : Освіта, 2004. - 352 c.

10. Українська мова: [підручник для 10-11 класів шкіл з українською та російською мовами навчання] / Біляєв О. М., Симоненкова Л. М., Скуратівський Л. В., Шелехова Г. Т. - [7-ме вид., перероб. і доп.] - К. : Освіта, 2004. - 240 с.

11. Устрицкий И. В. Изучение основ фонетики в средней школе / И. В. Устрицкий / под. ред. М. И. Матусевич. - Л. : Учпедгиз, 1948. - 136 с. 